\title{
The New Swiss-Israeli Tax Treaty
}

Hugues Salomé, PricewaterhouseCoopers SA, Lausanne, Switzerland

Dr. Robert J. Danon, Baker \& McKenzie, Geneva and Assistant Professor of tax law, University of Lausanne, Switzerland

George Rosenberg, Rosenberg, Keren-Polak \& Co, Advocate, Tel-Aviv/Haifa, Israel; Zurich, Switzerland ${ }^{1}$

\section{Introduction}

Six years ago Israel and Switzerland entered into a negotiation process with a view to concluding a double taxation convention in the field of the income and wealth taxes (the Treaty). After several rounds of negotiations, a draft Treaty was initialled on 22 January 2002. After approval, on the Swiss side by the Swiss cantons as well as the interested business circles and, on Israeli side, by the Israeli Government, the Treaty was signed on 2 July 2003. The Treaty, which is to a large extent patterned upon the OECD Model Convention (OECD MC), finally entered into force on 22 December 2003. ${ }^{2}$ Its provisions apply, however, retroactively as from 1 January 2002.

The present contribution therefore briefly reviews the features of the Treaty and in particular those that deviate from the OECD MC. Particular attention will also be paid to the Protocol to the Treaty, which was signed on 2 July 2003 (the Protocol).

\section{Definitions}

In line with the OECD MC, Article 3 of the Treaty defines the terms that appear in other Treaty provisions, such as 'person', 'company', 'enterprise of a Contracting State', etc. ${ }^{3}$

Like the corresponding provision of the OECD MC, Art. 3, para. 2 of the Treaty provides that:

'as regards the application of the Convention at any time by a Contracting State, any term not defined therein shall, unless the context otherwise requires, have the meaning that it has at that time under the law of that State for the purposes of the taxes to which the Convention applies, any meaning under the applicable tax laws of that State prevailing over a meaning given to the term under other laws of that State.'

Yet, taking account of the peculiarities of the Israeli

\section{Notes}

The present contribution is a revised and updated version of a presentation that was given by the authors at the Swiss-Israeli chamber of commerce in the course of June 2003.

2 The Israeli Income Tax Commission, however, permitted the application of the withholding tax provisions of the Treaty even before the Treaty entered into force, provided a suitable guaranty was produced by the taxpayer.

3 Noteworthy, Art. 3, para. 1, let. a)(ii) provides that "the term "Israel" means the State of Israel; and when used in a geographical sense, the term "Israel" includes its continental shelf and other maritime areas over which it exercises sovereign rights and jurisdiction according to international law'. This does, however, not include 'occupied' territories. Therefore, double taxation will not be eliminated when it occurs between Switzerland and these territories, FF 20035096. 
tax system, point 1 of the Protocol specifies that as far as Israel is concerned the term 'law' includes laws, regulations, administrative circulars and jurisprudence.

\section{Allocation of taxing rights}

Pursuant to the OECD MC the Treaty provides for a set of distributive rules (Arts. 6-22 of the OECD MC), which allocate taxing jurisdiction between the Contracting States.

\section{A. Business Profits (Article 7)}

Article 7 of the Treaty corresponds to the OECD MC and thus stipulates the profits of an enterprise of a Contracting State shall be taxable only in that State unless the enterprise carries on business in the other Contracting State'. Interestingly, point 2 of the Protocol provides that where an enterprise of a Contracting State sells goods or carries on an activity in the other Contracting State through a permanent establishment, the profits of the latter shall not be determined by reference to the profits realized by the whole enterprise but rather according to the remuneration that is solely attributable to such permanent establishment. The Protocol is here in line with the desire of Swiss tax authorities to promote, as a general rule, the use of the so-called 'direct method' as regards the allocation of income to a permanent establishment.

\section{B. Dividends (Article 10), Interests (Article 11) and Royalties (Article 12)}

The Dividend and Interest Articles correspond in essence to the provisions of Articles 10 and 11 of the OECD MC. Yet, the Treaty provides for a few exceptions, which clearly aim at promoting the Israeli economy.

First, besides the usual 5 per cent (inter-company dividends) and 15 per cent (general rule) residual tax that the state of source may levy, Art. 10, para. 2, letter $\mathrm{b}$ of the Treaty stipulates that the withholding tax levied in the state of source on dividends paid by an Israeli company to a Swiss resident company shall not exceed ' 10 percent of the gross amount of the dividends, not withstanding the provisions of subparagraph a), if the beneficial owner is a company which holds directly at least 10 percent of the capital of the company paying the dividend where that latter company is a resident of Israel and the dividends are paid out of profits which are subject to tax in Israel at a rate which is lower than the normal rate of Israeli company tax' (emphasis added).

Secondly, Article 11, para. 2, letter a) of the Treaty also provides that interest may also be taxed in the Contracting State in which it arises and according to the laws of that State, but if the recipient is the beneficial owner of the interest the tax so charged shall not exceed 5 per cent of the gross amount of the interest in the case of interest arising in a Contracting State and paid on any loan of whatever kind granted by a bank of the other contracting State'. This situation would for instance typically address a situation where a Swiss bank would grant a loan to an Israeli resident. ${ }^{4}$

Finally, in certain circumstances, a zero withholding tax rate is also applicable to interest remunerating loans granted in a business context as well as government loans. Article 11, paras. 3 and 4 provide indeed that:

- Notwithstanding the provisions of paragraph 2, interest arising in a Contracting State and paid to a resident of the other Contracting State who is the beneficial owner thereof shall be taxable only in that other State to the extent that such interest is paid to the seller of any industrial, commercial or scientific equipment, or of any merchandise sold by him on credit.'

- 'Notwithstanding the provisions of paragraph 2 and 3, interest arising in a Contracting State shall be exempt from tax in that State if it is paid in relation to any loan granted by the Government of the other Contracting State, including its political subdivisions and local authorities, the Central Bank of the other Contracting State or any financial instrumentality of that Government as may be agreed upon by the competent authorities of the Contracting States.'

According to Art. 12, para. 2 of the Treaty, the residual rate applicable by the state of source to royalties paid to a resident of the other Contracting State amounts to 5 per cent. For the time being, this provision will only have an impact on royalties paid by Israeli residents, as these payments are out of the scope of the Swiss 35 per cent withholding tax.

\section{Capital gains}

Article 13 of the Treaty corresponds to a very large extent to the corresponding provision of the OECD MC. Yet, like in eleven other double tax treaties, Art. 13, para. 4 of the Treaty provides that 'gains from the alienation of shares of the capital stock of a company, the property of which consists, directly or indirectly, principally of immovable property situated in a Contracting State, may be taxed in that State'. This provision is designed to allow Switzerland to levy, at the cantonal level, a real estate gain tax, on the disposal of shares of companies which are mainly engaged in the 
management of real estate located in Switzerland (socalled 'real estate property companies'). ${ }^{5}$

\section{Elimination of double taxation}

In line with Switzerland's long-standing treaty policy, the Treaty provides that Switzerland shall eliminate double taxation through the use of the exemption method. The credit method remains nonetheless applicable to dividends, interest and royalties.

With regards to capital gains stemming from the disposal of shares of Israeli real estate property companies, Art. 23, para. 1, letter a) of the Treaty provides that the exemption will be granted only if actual taxation of such gains in Israel is demonstrated. According to the practice of the Swiss tax authorities, this does not mean that the Swiss seller is required to effectively pay tax in Israel in any case. For instance, such gain would also be viewed as actually taxed if Israel would allow it to be compensated with losses incurred on the sale of other shares.

As far as Israel is concerned, double taxation will generally be eliminated by way of the credit method (Art. 23, para. 2 of the Treaty).

\section{Other provisions - exchange of information}

The other provisions of the Treaty are perfectly in line with other Swiss treaties. This is also true with regard to the exchange of information.

\section{A. The Protocol}

The Protocol contains, a few important peculiarities, which go far beyond mere clarifications. Paragraph 5 of the Protocol contains for instance a general subject-totax clause aimed at protecting the taxing rights of Switzerland. This provision provides indeed that as long as Swiss source income derived by a resident of Israel:

- is subject to Israeli taxes pursuant to the law applicable in Israel by reference to the amount received in Israel rather than by reference to the total amount, or

- is tax exempt in Israel,

it is understood that the exemption or the reduction of the Swiss taxes provided by the Treaty will apply only to the portion of the Swiss source income which is paid in Israel or effectively subject to tax in this country.
This being said, the impact of this provision should be partially limited, since Israel recently departed from its former 'remittance basis' tax system. Indeed, until 31 December 2002 the tax system in Israel was based largely on a territorial/remittance basis of taxation. That is, ordinary income was taxed if it was accrued, derived or received in Israel, largely without regard to the residency of the taxpayer. As a result, foreignsourced passive ordinary income (i.e. dividends, interest, rents, etc.) earned by Israeli residents was not taxable in Israel so long as it was not first remitted to Israel.

Yet, as of 1 January 2003, the tax system in Israel has been changed to a personal one analogous to Switzerland's worldwide unlimited tax liability. Specifically, Israeli residents are now taxed on their worldwide income whether remitted to Israel or not. In this regard and in the light of this change, the provision in Point 5 has now become largely academic. However, the text of this provision remains ambiguous in other respect. Further discussions should therefore take place in the course of this year between representatives of both states.

Paragraph 7 of the Protocol addresses situations in which a resident (for example an individual) of a Contracting State (for example Israel) takes up residence in the other Contracting State (Switzerland), while remaining the shareholder of a company of the first state (Israel). In such case, the state of former residence of the shareholder may tax capital gains on direct or indirect sale of shares in such company for a period of two years after the shareholder ceased to be a resident.

Yet, as part of the tax reform which came into force on 1 January 2003, Israel now has an 'exit tax', according to which a person (individual or corporate) who ceases to be a resident of Israel shall be deemed to have sold his/its capital assets on the day he/it ceased to be a resident. The payment of the capital gains tax, that may be due as a result of such 'sale', may be postponed to the date of actual sale of the asset.

In respect of ex-Israeli resident individuals, therefore, this 'exit tax' would seem to render the provision of Point 7 meaningless since, under any circumstances, the assets had already been 'sold' on the date of departure from Israel and such 'sale' is either subject to immediate payment of the capital gains tax, or if the departing individual so opts, the tax will only be paid upon actual sale. ${ }^{6}$

As currently Switzerland does not levy capital gains tax on the sale of shares of a company (aside from a real estate property company), ${ }^{7}$ Point 7 does not create a problem. Should the law in Switzerland

\section{Notes}

Robert Danon and Hugues Salomé, 'Avoidance of Double Non-Taxation' (Swiss national report) in (Michael Lang (ed.)), Schriftenreihe zum internationalen Steuerrecht, vol. 26 (Vienna, 2003), p. 5.

6 In such case, the taxable gain will be the real gain at the date of actual sale multiplied by the period in which asset was held from the date purchase to the date of cessation of residency, and divided by the total period in which the asset was held from the date of purchase to the date of actual sale. Interest and linkage differences due on the payment will only be calculated from the date of actual sale to the date of actual payment.

This is true for individual but also for corporate shareholders, to the extent that the latter may avail of either the so-called 'pure holding' regime (at cantonal level) and/or of the 'participation reduction' (at federal and, to the extent that the pure holding regime does not apply, cantonal level). 
change ${ }^{8}$ however, it would be interesting to see how the countries would resolve the conflict that would arise when a former Israeli resident, residing in Switzerland for more than two years, actually sold shares that he owned prior to relocating to Switzerland, thereby making him subject, from the Swiss point of view, to the 'new' Swiss capital gains tax.

Paragraph 8 of the Protocol finally clarifies that domestic law and procedure supersedes the provisions of the Treaty insofar as abuse of law (including tax treaties) is concerned and that Treaty benefits shall not be granted to a person who is not the beneficial owner of the particular item of income sourced in the other state.

This broad provision may create a particular problem for legitimate Israeli tax planning because of the very wide definition of 'law' - as it pertains to Israel - in Point 1 of the Protocol (see above). Thus, the Israeli tax authorities may argue that any use of the Treaty, which is in conflict, not only with the general anti-abuse provisions of the Income Tax Ordinance, ${ }^{9}$ but also with Interpretive or Practice Circulars which have been issued by the tax authorities, constitutes 'abuse of law'. Some of these Circulars, none of which are considered 'law' under Israel domestic law, rule out certain examples of legitimate tax planning although such tax planning is not in conflict with any legislation nor has it been ruled out by the courts to date.

\section{Concluding remarks}

As we have seen, the Treaty deviates in some respects from the OECD MC. Several provisions are in particular very favourable to Israeli taxpayers. This is for instance the case of the zero rate that applies to interest remunerating loans granted in a business context or government loans. From this perspective, the Treaty is expected to foster cross-border investments between Switzerland and Israel. Yet, a few issues still need to be clarified. Further discussions are therefore expected to take place between representatives of both states in the course of this year.

\section{Notes}

8 The Federal Council has indeed recently released a draft legislation aimed at achieving a better tax neutrality regarding decisions to invest in one or the other legal forms available in Switzerland for business activities as well as financing decisions. Depending on the model that will ultimately be chosen, capital gains realized by individuals on the disposal of substantial participations might, in certain circumstances, become taxable.

9 Section 86: 'If the Assessing Officer holds that a certain transaction - which reduces or is likely to reduce the amount of tax payable by any person - is artificial or fictitious .... then he may disregards that transaction or disposition and the person concerned shall be assessed accordingly; avoidance or reduction of tax may be deemed improper even if it is not contrary to Law .... 